\title{
Cardiovascular risk factors: differences between ethnic groups
}

\author{
Fatores de risco cardiovascular: diferenças entre grupos étnicos \\ Factores de riesgo cardiovascular: diferencias entre grupos étnicos
}

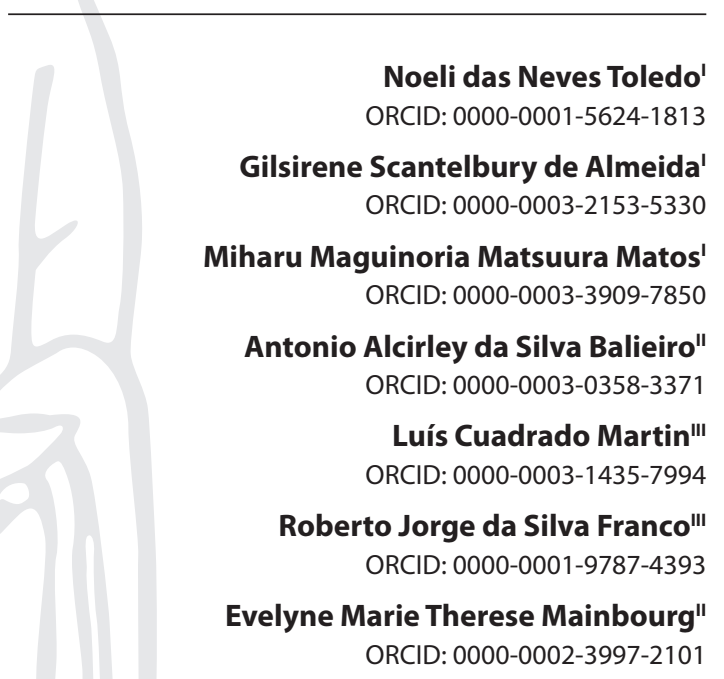

'Universidade Federal do Amazonas, Manaus, Amazonas, Brazil "Fundação Oswaldo Cruz. Manaus, Amazonas, Brazil I'Universidade Estadual Paulista Júlio de Mesquita Filho.

Botucatu, São Paulo, Brazil

How to cite this article: Toledo NN, Almeida GS, Matos MMM, Balieiro AAS, Martin LC, Franco RJS, Mainbourg EMT. Cardiovascular risk factors: differences between ethnic groups.

Rev Bras Enferm. 2020;73(4):e20180918 doi: http://dx.doi.org/10.1590/0034-7167-2018-0918

\section{Corresponding author:}

Evelyne Marie Therese Mainbourg E-mail: evelyne.mainbourg@gmail.com

EDITOR IN CHIEF: Dulce Aparecida Barbosa ASSOCIATE EDITOR: Marcia Magro

Submission: 03-22-2019

Approval: 10-12-2019

\section{ABSTRACT}

Objectives: to compare the metabolic, anthropometric, tobacco and alcohol consumption indicators considered as risk factors for cardiovascular diseases, as well as the demographic and socioeconomic characteristics between indigenous from Rio Negro, Sateré-Mawé, mixed-race/ black and white people living in the city of Manaus. Methods: a cross-sectional observational study guided by the STROBE tool. There was a sample of 191 adults of both sexes. Anthropometric measurements, blood pressure and biochemical analyzes were performed. Statistical test was applied to cross color/race/ethnicity variable with the investigated variables. Results: indigenous had better metabolic and anthropometric indicators related to cardiovascular diseases than mixed-race/black and white, as well as Sateré-Mawé in relation to Rionegrinos (from Rio Negro). Conclusions: the main differences were obesity, dyslipidemia, pre-systemic arterial hypertension/ systemic arterial hypertension, and increased circumferences, with a worse situation for mixedrace/black people. The findings indicate differences in risk factors between race/color and ethnicity groups evaluated.

Descriptors: Cardiovascular Diseases; Risk Factors; Indigenous Population; Ethnic Groups; Urban Population.

\section{RESUMO}

Objetivos: comparar os indicadores metabólicos, antropométricos, de consumo de tabaco e álcool, considerados como fatores de risco para doenças cardiovasculares, assim como as características demográficas e socioeconômicas entre indígenas do Rio Negro, Sateré-Mawé, Pardos/Negros e Brancos que residem na cidade de Manaus. Métodos: estudo observacional transversal, norteado pela ferramenta STROBE. Amostra de 191 adultos de ambos os sexos. Realizadas medidas antropométricas, pressão arterial e análises bioquímicas. Aplicado teste estatístico no cruzamento da variável cor/raça/etnia com as variáveis investigadas. Resultados: os indígenas apresentaram melhores indicadores metabólicos e antropométricos relacionados às doenças cardiovasculares que os pardos/negros e brancos, assim como os Sateré-Mawé em relação aos rionegrinos. Conclusões: as principais diferenças foram: obesidade, dislipidemia, pré-hipertensão arterial sistêmica/hipertensão arterial sistêmica e circunferências aumentadas, com destaque de pior situação para os pardos/negros. Os achados indicam haver diferenças nos fatores de risco entre os grupos de raça/cor e etnia avaliados.

Descritores: Doenças Cardiovasculares; Fatores de Risco; População Indígena; Grupos Étnicos; Área Urbana.

\section{RESUMEN}

Objetivos: comparar los indicadores metabólicos, antropométricos, de consumo de tabaco y alcohol considerados como factores de riesgo para enfermedades cardiovasculares, así como las características demográficas y socioeconómicas entre los indígenas del Rio Negro, SateréMawé, población de raza mixta/negra y blanca que viven en la ciudad de Manaus. Métodos: estudio observacional transversal, guiado por la herramienta STROBE. La muestra consistió en 191 adultos de ambos sexos. Se realizaron mediciones antropométricas, presión sanguínea y análisis bioquímicos. La prueba estadística se aplicó a la variable de color/raza/etnia con las variables investigadas. Resultados: los indígenas tenían mejores indicadores metabólicos y antropométricos relacionados con las enfermedades cardiovasculares que los de raza mixta/ negros y blancos, así como los Sateré-Mawé en relación con los rionegrinos (del Rio Negro). Conclusiones: las principales diferencias fueron: obesidad, dislipidemia, pre-hipertensión arterial sistémica/ hipertensión arterial sistémica y aumento de las circunferencias, con una situación peor para los raza mixta/negros. Los resultados indican diferencias en los factores de riesgo entre los grupos de raza/color y etnia evaluados.

Descriptores: Enfermedades Cardiovasculares; Factores de Riesgo; Población Indígena; Grupos Étnicos; Área Urbana. 


\section{INTRODUCTION}

Worldwide data show that cardiovascular disease (CVD) is considered the leading cause of death from chronic noncommunicable diseases (NCDs) ${ }^{(1)}$. Risk factors considered modifiable for the onset of CVD are systemic arterial hypertension (SAH), smoking, hypercholesterolemia, diabetes mellitus (DM), obesity, abdominal obesity, sedentary lifestyle, poor fruit and vegetable diet, and psychosocial stress( ${ }^{(2)}$.

National data indicate that SAH accounts for $50 \%$ of stroke deaths ${ }^{(3)}$. They also show that for chronic kidney disease (CKD) associated with $\mathrm{DM}$, mortality is estimated at around $30 \%{ }^{(2)}$.

With respect to specific populations, studies relate CVD growth to ethnic-racial inequalities because of the high mortality rate, social disruption and socioeconomic marginalization, especially between African descendants and indigenous populations ${ }^{(4-5)}$. In general, conflicts of cultural identity, changes in lifestyle and destruction of ecosystems have negatively interfered with the daily lives of diverse ethnic groups, particularly indigenous peoples. It is also noteworthy that the conditions of vulnerability in Brazilian indigenous populations are accentuated because they present the worst health indicators ${ }^{(6)}$. In this perspective, a systematic review study shows a worsening of the metabolic profile as a factor responsible for the vulnerability to the development of CVD, especially regarding the increased prevalence of $S A H$ and $D^{(7)}$.

Ethnic-racial characterization has been the subject of discussion in several areas of knowledge, especially in epidemiology where the categories color, race and ethnicity are used as variables of exposure to the disease $\mathrm{e}^{(4)}$. These categories are also considered essential dimensions for a better understanding about the distribution of health outcomes, enabling the elaboration of public policies more consistent with the needs of the population groups ${ }^{(8)}$. Finally, studies on the health status of indigenous people living in urban contexts in Brazil are still scarce, particularly regarding the risk factors for the development of cardiovascular diseases, and comparative approach with other ethnic-racial groups living in the same area.

\section{OBJECTIVES}

To compare metabolic, anthropometric and tobacco and alcohol consumption which are considered as risk factors for cardiovascular diseases, as well as socioeconomic demographic characteristics between indigenous from Rio Negro, Sateré-Mawé, mixed-race/black and white living in the city of Manaus, state of Amazonas, Brazil.

\section{METHODS}

\section{Ethical aspects}

In accordance with the Brazilian National Health Board (Conselho Nacional de Saúde) Resolution 466 of 2012, which regulates the ethical aspects of research involving human subjects, the project was submitted and approved by the Research Ethics Committee of the Universidade Federal do Amazonas and the Brazilian Research Ethics Committee.

\section{Design, place of study and period}

This is a cross-sectional observational study, guided by the STROBE tool, which was conducted in Manaus from data collected between September 2011 and April 2012, in a sample consisting of adults of both sexes, indigenous people of different ethnic groups, white, mixed-race and black. It is noteworthy that, in relation to white, mixed-race and black people, the target population was the neighbor of the natives, because they share the same social and environmental conditions as the natives.

\section{Population and sample, inclusion and exclusion criteria}

Due to the scarcity and difficult access to indigenous groups in urban areas, a convenience sample was built from the invitation of five indigenous associations chosen to represent two thirds of the city's indigenous population. The other part of the sample (non-indigenous) was invited to the health units located in the areas of residence of the indigenous participants of the study. The inclusion criterion was to be over 18 years old. The exclusion criterion was waiting for a medical appointment for cardiovascular disease, including high blood pressure.

The total study sample consisted of 191 individuals, men and women, aged 18 to 65 years old living in a state capital, 78 (41\%) indigenous and 113 (59\%) non-indigenous (mixed-race, black and white people). Regarding ethnicity, 35 (45\%) indigenous people were Sateré-Mawé (from the Andirá and Maráu rivers region, relatively close to Manaus) and $43(55 \%)$ were from various ethnic groups from the far Upper Rio Negro region. (more than one-hour flight):Tukano, Baré, Desana, Tariano, Tuyuca, Piratapuia, Arapaço and others. As for the 113 non-indigenous individuals, 42 (37\%) were neighbors of the Sateré-Mawé indigenous and 71 (63\%) were neighbors of the Rio Negro indigenous. The sample was categorized into four groups: Sateré-Mawé indigenous, Upper Rio Negro indigenous (hereinafter called Rionegrinos), whites and mixed-race people/blacks (grouped because of the low number of black people in the universe of the study population).

\section{Study protocol}

For the indigenous population, given their small proportion of the city's population and its large dispersal, the best recruitment strategy was to go through the indigenous associations' members. In addition to being study participants, they assumed an important role in contact with other families of the same ethnic group and/or indigenous area of origin. These indigenous associations were chosen because the ethnic groups they represent constitute an important share (two thirds) of the indigenous population of Manaus ${ }^{(9)}$ and because they are representative, which made it easier for them to locate and communicate with them. The associations included were: Waikirú, Bayaroá, Yápyrehyt, AMISM (freely translated as Associação das Mulheres Indígenas Sateré-Mawé - Sateré-Mawé Indigenous Women Association) and AMARN (freely translated as Associação das Mulheres do Alto Rio Negro - Upper Rio Negro Women's Association). Indigenous data were collected at the headquarters of the Waikirú, Bayaroá and Y'apyrehyt (Sateré-Mawé) associations and at the AMARN headquarters, which represents the Rio Negro ethnic groups. 
Recruitment and data collection of non-indigenous study participants were conducted in the areas of residence of indigenous participants, in Primary Health Care Units and in two of the city's four polyclinics, one located in the North Zone and the other in the East Zone. two areas where most of Manaus's population lives. Individuals who were waiting for a medical appointment or nursing procedure were recruited, and individuals who were waiting for consultation due to cardiovascular disease, including hypertension, were excluded from the study. In addition, it is worth noting that the data collection period coincided with the registration of families for the distribution of milk to parents who had children under two years of age. Thus, we sought to prioritize the invitation to community members who were in the health unit for this registration, rather than presenting signs or symptoms of disease.

Demographic and socioeconomic data (gender, age, time in Manaus, occupation, marital status, number of people per household and religion) were evaluated, with the purpose of characterizing the sample. Regarding cardiovascular risk factors, we evaluated the values of systemic blood pressure (SBP), body mass index (BMI), waist circumference (WC), waist hip ratio (WHR), serum glucose levels, total cholesterol/fractions, as well as smoking and alcohol consumption.

For the casual measurement of SBP, we used an automatic monitor (with an armband for adults or obese individuals, according to arm circumference), model HEM-742INT - OMRON, being considered high pressure when the average of the three measurements was $\geq 120$ and $\geq 80$ $\mathrm{mmHg}^{(2)}$. Measurements of the circumferences were performed using a nonelastic tape measure and were considered increased when: neck (WC) $\geq 37 \mathrm{~cm}$ men and $\geq 34 \mathrm{~cm}$ women; waist (WC) $\geq 94 \mathrm{~cm}$ in men and $\geq 80 \mathrm{~cm}$ in women. Body fat mass was verified from the ratio WHR and was considered high when $\geq 0.90$ in men and $\geq 0.80$ in women. To measure weight, we used a portable electronic platform scale and height was measured using a portable stadiometer. BMI was classified according to the following cutoff points: normal or low when $<25$, preobese when between 25.0 and 29.9 and obese when $\geq 30^{(10)}$. All participants were previously instructed to be fasting for eight hours to collect a $10 \mathrm{ml}$ blood sample. In the biochemical analyzes, the tests with their respective abnormality values adopted were: Blood glucose ( $\geq 100 \mathrm{mg} / \mathrm{dL}$ ); Total Cholesterol ( $\geq 200 \mathrm{mg} / \mathrm{dL}) ; \mathrm{HDL}(<40 \mathrm{mg} /$ $\mathrm{dL}) ; \mathrm{LDL}(\geq 130 \mathrm{mg} / \mathrm{dL}) ; \mathrm{VLDL}(<30 \mathrm{mg} /$ $\mathrm{dL}$ ) and Triglycerides ( $\geq 150 \mathrm{mg} / \mathrm{dL}$ ). LDL was calculated by Friedewald's formula (LDL=total cholesterol-HDL-VLDL), where VLDL=triglycerides $\div 5^{(11)}$.

\section{Analysis of results, and statistics}

A descriptive analysis of the variables of interest was performed according to the Sateré-Mawé, Rionegrino, mixed-race/black and white groups. All variables were categorized and compared by Pearson's $X 2$ test or Fisher's exact test, when the expected value on a given square was $<5$. The significance level considered in the tests was $p<0.05$.

\section{RESULTS}

Table 1 presents the demographic, socioeconomic and habits characteristics (alcohol consumption and smoking) of the groups under study. Attention is drawn to the profile of the living conditions of indigenous people, especially the Sateré-Mawé, who seem to be more unfavorable (unemployment, number of people in the household) than the profile of mixed-race/black and white population.

Table 1 - Demographic, socioeconomic and habits characteristics according to race/color and ethnicity, Manaus, Amazonas, Brazil, 2011-2012

\begin{tabular}{|c|c|c|c|c|c|c|}
\hline \multirow[b]{2}{*}{ Variable } & \multicolumn{5}{|c|}{ Race/color and ethnicities } & \multirow[b]{2}{*}{$\begin{array}{c}p \\
\text { value }\end{array}$} \\
\hline & $\begin{array}{c}\text { Sateré- } \\
\text { Mawé } \\
\mathbf{n = 3 5}(\%)\end{array}$ & $\begin{array}{c}\text { Rionegrinos } \\
n=43(\%)\end{array}$ & $\begin{array}{c}\text { Mixed-race/ } \\
\text { blacks } \\
n=89(\%)\end{array}$ & $\begin{array}{c}\text { Whites } \\
n=24 \text { (\%) }\end{array}$ & $\begin{array}{c}\text { Total } \\
\text { N= } 191 \text { (\%) }\end{array}$ & \\
\hline Sex & & & & & & 0.016 \\
\hline Male & $16(45.7)$ & $10(23.3)$ & $20(22.5)$ & $11(45.8)$ & $57(29.8)$ & \\
\hline Female & $19(54.3)$ & $33(76.7)$ & $69(77.5)$ & $13(54.2)$ & $134(70.2)$ & \\
\hline Age group & & & & & & $<0.001$ \\
\hline $18-29$ years & $15(42.9)$ & $3(7.0)$ & $17(19.1)$ & $9(37.5)$ & $44(23.0)$ & \\
\hline $30-39$ years & $13(37.1)$ & $8(18.6)$ & $22(24.7)$ & $4(16.7)$ & $47(24.7)$ & \\
\hline $40-49$ years & $2(5.7)$ & $15(34.9)$ & $21(23.6)$ & $5(20.8)$ & $43(22.5)$ & \\
\hline $50-59$ years & $2(5.7)$ & $5(11.6)$ & $24(27.0)$ & $4(16.7)$ & 35 (18.3) & \\
\hline 60 years and + & $3(8.6)$ & $12(27.9)$ & $5(5.6)$ & $2(8.3)$ & $22(11.5)$ & \\
\hline Time in Manaus & & & & & & $<0.001$ \\
\hline $0-15$ years & $17(48.6)$ & $21(48.8)$ & $20(22.5)$ & $7(29.2)$ & $65(34.0)$ & \\
\hline $16-30$ years & $12(34.3)$ & $17(39.5)$ & $31(34.8)$ & $8(33.3)$ & $68(35.6)$ & \\
\hline 31 years and + & $6(17.1)$ & $5(11.6)$ & $38(42.7)$ & $9(37.5)$ & $58(30.4)$ & \\
\hline Occupation & & & & & & $<0.001$ \\
\hline Employed or Retired & $19(54.3)$ & $32(74.4)$ & $80(89.9)$ & $21(87.5)$ & 152 (79.6) & \\
\hline Unemployed & $16(45.7)$ & $11(25.6)$ & $9(10.1)$ & $3(12.5)$ & $39(20.4)$ & \\
\hline Marital Status & & & & & & 0.006 \\
\hline With partner & $29(82.9)$ & $20(46.5)$ & $59(66.3)$ & $18(75.0)$ & $126(66.0)$ & \\
\hline Without partner & $6(17.1)$ & $23(53.5)$ & $30(33.7)$ & $6(25.0)$ & $65(34.0)$ & \\
\hline Religion & & & & & & $<0.001$ \\
\hline Evangelical & 31 (88.6) & $2(4.7)$ & $40(44.9)$ & $13(54.2)$ & $86(45.0)$ & \\
\hline Catholic & $4(11.4)$ & $41(95.3)$ & $43(48.3)$ & $9(37.5)$ & $97(50.8)$ & \\
\hline Others & $0(0)$ & $0(0)$ & $6(6.7)$ & $2(8.3)$ & $8(4.2)$ & \\
\hline People/domicile & & & & & & $<0.001$ \\
\hline 1 person & $4(11.4)$ & $4(9.3)$ & $15(16.9)$ & $1(4.2)$ & $24(12.6)$ & \\
\hline 2 people & $8(22.9)$ & $16(37.2)$ & $53(59.6)$ & $13(54.2)$ & $90(47.1)$ & \\
\hline 3 people and + & $23(65.7)$ & $23(53.5)$ & $21(23.6)$ & $10(41.7)$ & $77(40.3)$ & \\
\hline Smoking & & & & & & $<0.001$ \\
\hline Never smoked & $15(42.9)$ & $28(65.1)$ & $55(61.8)$ & $15(62.5)$ & $113(59.2)$ & \\
\hline Already smoked & $20(57.1)$ & $5(11.6)$ & $24(27.0)$ & $5(20.8)$ & $54(28.3)$ & \\
\hline Still smokes & $0(0)$ & $10(23.3)$ & $10(11.2)$ & $4(16.7)$ & $24(12.6)$ & \\
\hline Alcohol (the last 7 days) & & & & & & $<0.001$ \\
\hline No & $30(85.7)$ & $26(60.5)$ & $81(91.0)$ & $17(70.8)$ & $154(80.6)$ & \\
\hline Yes & $5(14.3)$ & $17(39.5)$ & $8(9.0)$ & $7(29.2)$ & $37(19.4)$ & \\
\hline Alcohol consumption & & & & & & $<0.001$ \\
\hline Never drunk & $8(22.9)$ & $36(83.7)$ & $22(24.7)$ & $10(41.7)$ & $76(39.8)$ & \\
\hline Already drunk & $15(42.9)$ & $3(7.0)$ & $25(28.1)$ & $9(37.5)$ & $52(27.2)$ & \\
\hline Still drinks & $12(34.3)$ & $4(9.3)$ & $42(47.2)$ & $5(20.8)$ & $63(33.0)$ & \\
\hline
\end{tabular}


Table 2 - Anthropometric, metabolic and blood pressure variables by race/color and ethnicity, Manaus, Amazonas, Brazil, 2011-2012

\begin{tabular}{|c|c|c|c|c|c|c|}
\hline \multirow[b]{2}{*}{ Variable } & \multicolumn{5}{|c|}{ Race/color and ethnicities } & \multirow[b]{2}{*}{$\begin{array}{c}p \\
\text { value }\end{array}$} \\
\hline & $\begin{array}{c}\text { Sateré- } \\
\text { Mawé } \\
\mathrm{n}=\mathbf{3 5}(\%)\end{array}$ & $\begin{array}{c}\text { Rionegrinos } \\
n=\mathbf{4 3}(\%)\end{array}$ & $\begin{array}{c}\text { Mixed-race/ } \\
\text { blacks } \\
n=89(\%)\end{array}$ & $\begin{array}{c}\text { Whites } \\
n=24(\%)\end{array}$ & $\begin{array}{c}\text { Total } \\
\mathrm{N}=191 \text { (\%) }\end{array}$ & \\
\hline *BMI & & & & & & 0.008 \\
\hline Normal or low & $17(48.6)$ & $17(39.5)$ & $19(21.3)$ & $5(20.9)$ & $58(30.4)$ & \\
\hline Preobese & 15 (42.9) & 18 (41.9) & $37(41.6)$ & $12(50.0)$ & $82(42.9)$ & \\
\hline Obese & $3(8.6)$ & $8(18.6)$ & $33(37.1)$ & $7(29.2)$ & $51(26.7)$ & \\
\hline *WC Men & & & & & & 0.036 \\
\hline Normal & $13(81.2)$ & $9(90.0)$ & $9(45.0)$ & $6(54.50)$ & $37(64.9)$ & \\
\hline Increased & $3(18.8)$ & $1(10.0)$ & $11(55.0)$ & $5(45.50)$ & $20(35.1)$ & \\
\hline *WC Women & & & & & & 0.038 \\
\hline Normal & $12(63.2)$ & $9(27.3)$ & $20(29.0)$ & $5(38.5)$ & $46(34.3)$ & \\
\hline Increased & $7(36.8)$ & $24(72.7)$ & $49(71.0)$ & $8(61.5)$ & $88(65.7)$ & \\
\hline *WHR Women & & & & & & 0.047 \\
\hline Normal & $6(31.6)$ & $3(9.1)$ & $21(30.4)$ & $5(38.5)$ & $35(26.1)$ & \\
\hline Increased & $13(68.4)$ & $30(90.9)$ & $48(69.6)$ & $8(61.5)$ & 99 (73.9) & \\
\hline$\triangle \mathrm{SBP}$ & & & & & & 0.008 \\
\hline Normal & 25 (71.4) & $23(53.5)$ & $35(39.3)$ & $9(37.5)$ & $92(48.2)$ & \\
\hline$\triangle$ PreSAH /SAH & $10(28.6)$ & $20(46.5)$ & $54(60.7)$ & $15(62.5)$ & $99(51.8)$ & \\
\hline Total Cholesterol & & & & & & $<0.001$ \\
\hline Acceptable & $34(97.1)$ & $21(48.8)$ & $57(64.0)$ & $19(79.2)$ & $131(68.6)$ & \\
\hline Borderline/high & $1(2.9)$ & $22(51.2)$ & $32(36.0)$ & $5(20.8)$ & $60(31.4)$ & \\
\hline${ }^{\dagger} \mathrm{HDL}$ & & & & & & 0.011 \\
\hline Normal/great & $19(54.3)$ & $33(76.7)$ & $42(47.2)$ & $11(45.8)$ & $105(55.0)$ & \\
\hline Low & $16(45.7)$ & $10(23.3)$ & $47(52.8)$ & $13(54.2)$ & $86(45.0)$ & \\
\hline${ }^{+} \mathrm{LDL}$ & & & & & & $<0.001$ \\
\hline Acceptable & $34(97.1)$ & $18(41.9)$ & $60(67.4)$ & $16(66.7)$ & $128(67.0)$ & \\
\hline Borderline/high & $1(2.9)$ & $25(58.1)$ & $29(32.6)$ & $8(33.3)$ & $63(33.0)$ & \\
\hline †VLDL & & & & & & 0.002 \\
\hline Normal/great & $4(11.4)$ & $12(27.9)$ & $41(46.1)$ & 7 (29.2) & $64(33.5)$ & \\
\hline Low & 31 (88.6) & $31(72.1)$ & 48 (53.9) & $17(70.8)$ & $127(66.5)$ & \\
\hline Triglycerides & & & & & & 0.001 \\
\hline Normal & 31 (88.6) & $32(74.4)$ & 48 (53.9) & $17(70.8)$ & $128(67.0)$ & \\
\hline Borderline/high & $4(11.4)$ & $11(25.6)$ & $41(46.1)$ & $7(29.2)$ & $63(33.0)$ & \\
\hline Fasting Blood & & & & & & \\
\hline Glucose & & & & & & 0.036 \\
\hline Normal & $35(100.0)$ & 35 (81.4) & $71(79.8)$ & $21(87.5)$ & $162(84.8)$ & \\
\hline -Tolerance/DM & $0(0.0)$ & $8(18.6)$ & $18(20.2)$ & $3(12.5)$ & $29(15.2)$ & \\
\hline
\end{tabular}

Note: *BMI - Body Mass Index; *WC - Waist Circumference; *WHR - Waist-to-Hip Ratio; ${ }^{\mathbf{A} S B P}$ - Systemic Blood Pressure $\triangle$ PreSAH/SAH - Prehypertension/Systemic Arterial Hypertension; $+H D L$ - High Density Lipoproteins; $+L D L$ - Low Density Lipoproteins; TVLDL - Very Low Density Lipoproteins; -Tolerance/DM - Decreased glucose tolerance/Diabetes Mellitus. found in studies conducted in the Brazilian population ${ }^{(3-4,6-7,12)}$

It is noteworthy that SAH was even lower than studies conducted with indigenous people living in the various Brazilian regions. Among the Kaingang, the prevalence of hypertension suggestive of hypertension was $53.2 \%$ among men and $40.7 \%$ among women $(p=0.02)^{(13)}$. SAH was also lower in other countries, pointing out that the high prevalence is associated with the adoption of western eating habits, sedentary lifestyle, increased life expectancy and urbanization process of the population ${ }^{(8,14-16)}$.

A study of northeastern indigenous populations affected by the rapid urbanization process showed higher risk of cardiovascular mortality $^{(17-18)}$. From the findings, we can consider that there is a possibility that the indigenous of Manaus were not so affected by the urbanization process, because they managed to maintain a way of life close to that they had in indigenous lands. In fact, in the case of the Sateré Mawé, mechanisms and strategies of "indigenization of the city"(9) ${ }^{\prime \prime}$ were created involving a network of practices and social relations that allow the maintenance of the traditional way of life or its reinvention, such as the disposition of houses around a central social space where they perform community activities, including rituals. This would explain the better BMI values between the Sateré-Mawé and Rio Negro indigenous compared to the indigenous from other regions of Brazil and from other countries for which obesity is a frequent problem. As an example, a study identified overweight in $66 \%$ of Xingu indigenous, in which $52 \%$ were classified as abdominal obesity. Similarly, the Kaingang and Guarani indigenous were mostly classified as obese $^{(19)}$. In the comparison by gender, studies
Table 2 presents the anthropometric, metabolic and blood pressure variables of the groups investigated, showing a worse profile for mixed-race and black group and a better profile for Sateré-Mawé. Aside from the high rate of preobese in all groups, the combination of indicators outside the normal range is different from one group to another. Mixed-race/black population, with a high percentage of individuals having abnormally high or abnormally low values (depending on the indicator) in eight of the eleven variables, is the group with the worst situation. In contrast, the Sateré-Mawé have only one variable with a high percentage in the risk category, with a large difference with the Rionegrinos who are most similar to the two non-indigenous groups.

\section{DISCUSSION}

In this study, it was found that the prevalence of hypertension among indigenous people was lower than that of whites and mixed-race/black population, as well as the prevalence showed that women of the Xavante ethnic group had the highest BMI over $30 \mathrm{~kg} / \mathrm{m}^{2}$, as well as the indigenous women of the Kaiowá, Guarani and Terena ethnic groups from the Jaguapiru village, who were obese in the highest proportion (30\%) compared to men (14\%) $)^{(20-21)}$.

It is noteworthy that the highest percentages of individuals with DM or glucose intolerance were between mixed-race/black population and Rionegrinos, while no Sateré-Mawé population showed abnormalities in blood glucose. A study carried out with indigenous Xavante ethnic groups identified high prevalence of high cardiovascular risk, highlighting blood glucose values as one of the indicators that presented higher percentages, especially among women $(70.2 \%)^{(20)}$.

When comparing the metabolic and anthropometric profile of the Aruák indigenous (Mehinaku, Waurá and Yawalapetí) from the Upper Xingu, Gimeno et al. noted that this population had high percentages of overweight (66\%), abdominal obesity (52\%) and dyslipidemia (77.1\%). It was suggested that increased percentage 
of adipose tissue, reduced prevalence of infectious diseases and changes in eating habits and lifestyle were the main factors contributing to the increase in NCDs in the investigated group ${ }^{(7,12)}$.

The adequate BMI of the indigenous people in this study may explain the favorable values of blood glucose and total cholesterol found, considering that the metabolic changes are explained by the increase in BMI, physical inactivity and or irregular physical activity. Among the Mura indigenous, whose prevalence of SAH was $26 \%$, more than half of the study participants were overweight and sedentary. The findings indicate that the group probably adopted inappropriate habits and lifestyles, requiring actions aimed at controlling cardiovascular risk factors and associated diseases ${ }^{(19)}$.

Studies conducted with indigenous people living in other countries also presented differences in risk factor profiles for the development of CVD when compared to non-indigenous people. The results showed that, in Australia, the absolute risk for CVD in indigenous people followed for a period of 20 years increased as waist circumference and age values also increased ${ }^{(16)}$. In Canada, study showed interethnic differences. Among them, the lower prevalence of heart disease, diabetes, and hypertension in the Inuit group was attributed to greater adherence to traditional lifestyles, while indigenous people living in southern Canada had higher prevalence ${ }^{(14)}$.

The frequency of hypertension and cardiometabolic risk factors is noticeably low in the present study, which can probably be explained by the similarity of life habits with those of the villages.

When evaluating, in this study, a group of urban indigenous people who maintained their weight in adequate borderlines, it was not observed the increase of cardiovascular risk factors presented in other urban or village indigenous groups evaluated in other studies in Brazil.

\section{Study limitations}

The main limitation of the study is the convenience sample, which was necessary due to the large dispersion of the indigenous population in the city, associated with a very small total population within the general population of the city. Despite this difficulty in recruiting indigenous subjects, their strong bond with their associations allowed them to be recruited. The total sample of indigenous subjects was not large, but the statistical tests were valid.

\section{Contributions to nursing, health or public policy}

These results draw attention to the most vulnerable groups due to a risk factor little taken into consideration in the literature, the color/race factor and also ethnicity and, therefore, about the importance of greater incorporation of this variable in the information systems. From now on, it is recommended that nursing teams make efforts not to omit these characteristics when approaching patients with abnormal biological values. The study also shows the need for further investigations in this perspective, with larger and representative samples, considering that comparative studies of color/race and ethnicity groups on health conditions in urban areas are still scarce.

\section{CONCLUSIONS}

The findings indicate that, in relation to cardiovascular risk factors, the main differences identified between the groups were obesity, dyslipidemia, preSAH/SAH and increased circumferences, indicating mixed-race/black group as the most vulnerable. It is noteworthy that Rionegrinos presented an anthropometric, metabolic and blood pressure profile similar to those of nonindigenous people, indicating more prevalent cardiovascular risk factors than in the Sateré-Mawé.

\section{ACKNOWLEDGMENT}

A special thanks to the AMISM (freely translated as Associação das Mulheres Indígenas Sateré-Mawé - Sateré-Mawé Indigenous Women Association), Waikirú, Bayaroá, Yápyrehyt (all Sateré-Mawé ethnicity) indigenous associations, and AMARN (freely translated as Associação das Mulheres do Alto Rio Negro - Upper Rio Negro Women's Association) for their collaboration in communicating and locating indigenous subjects and for the provision of collection site.

\section{REFERENCES}

1. World Health Organization (WHO). Noncommunicable diseases country profiles[Internet]. WHO. 2018[cited 2020 Apr 30]. Available from: http://www.who.int/nmh/publications/ncd-profiles-2018/en/

2. Malachias M. 7a Diretriz Brasileira de Hipertensão Arterial: apresentação. Arq Bras Cardiol. 2016;107(3 Suppl 3). doi: 10.5935/abc.20160140

3. Ministério da Saúde (BR). Secretaria de Vigilância em Saúde, Departamento de Análise em Saúde e Vigilância, de Doenças Não Transmissíveis. VIGITEL BRASIL 2018 - Vigilância de fatores de risco e proteção para doenças crônicas por inquérito telefônico - Posts | ACT BR [Internet]. ACT - Promoção da Saúde. 2018[cited 2020 Apr 30]. Available from: https://actbr.org.br/post/ vigitel-brasil-2018-vigilancia-de-fatores-de-risco-e-protecao-para-doencas-cronicas-por-inquerito-telefonico/18056/

4. Basta, PC, Orellana J, Arantes R. Perfil epidemiológico dos povos indígenas no Brasil: notas sobre agravos selecionados. In: Saúde Indígena: uma introdução ao tema. Brasília: MEC-SECADI; 2012. p. 60-107.

5. Ortegal L. Relações raciais no Brasil: colonialidade, dependência e diáspora. Serviço Soc Amp Soc. 2018;(133):413-31. doi: 10.1590/0101-6628.151

6. Instituto Brasileiro de Geografia e Estatística (IBGE) IBDGEE. Os indígenas no Censo Demográfico 2010: primeiras considerações com base no quesito cor ou raça. Rio de Janeiro: IBGE; 2012. 31 p. 
7. Souza Filho ZA, Ferreira AA, Santos B, Pierin AMG, Souza Filho ZA, Ferreira AA, et al. Hypertension prevalence among indigenous populations in Brazil: a systematic review with meta-analysis. Rev Esc Enferm USP. 2015;49(6):1012-22. doi: 10.1590/ S0080-623420150000600019

8. Boaretto JD, Molena-Fernandes CA, Pimentel GGA, Boaretto JD, Molena-Fernandes CA, Pimentel GGA. Estado nutricional de indígenas Kaingang e Guarani no estado do Paraná, Brasil. Ciênc Amp Saúde Coletiva. 2015;20(8):2323-8. doi: 10.1590/1413-81232015208.14462014

9. Magnani J, Andrade J. Uma experiência de Etnologia Urbana: a presença indígena em cidades da Amazônia. In: Paisagens ameríndias: lugares, circuitos e modos de vida na Amazônia. São Paulo: Terceiro Nome; 2013. p. 45-74.

10. Ministério da Saúde (BR). Secretaria de Atenção à Saúde, Departamento de Atenção Básica. Orientações para a coleta e análise de dados antropométricos em serviços de saúde: Norma Técnica do Sistema de Vigilância Alimentar e Nutricional - SISVAN. 2011.

11. Faludi A, Izar M, Saraiva J, Chacra A, Bianco H, Afiune Neto A, et al. Atualização da Diretriz Brasileira de Dislipidemias e Prevenção da Aterosclerose - 2017. Arq Bras Cardiol [Internet]. 2017 [cited 2020 Apr 30];109(1). Available from: http://www.gnresearch.org/doi/10.5935/ abc.20170121

12. Gimeno SGA, Rodrigues D, Pagliaro H, Cano EN, Lima EES, Baruzzi RG. Perfil metabólico e antropométrico de índios Aruák: Mehináku, Waurá e Yawalapití, Alto Xingu, Brasil Central, 2000/2002. Cad Saúde Pública. 2007;23(8):1946-54. doi: 10.1590/S0102-311X2007000800021

13. Bresan D, Bastos JL, Leite MS, Bresan D, Bastos JL, Leite MS. Epidemiology of high blood pressure among the Kaingang people on the Xapecó Indigenous Land in Santa Catarina State, Brazil, 2013. Cad Saúde Pública. 2015;31(2):331-44. doi: 10.1590/0102-311X00058714

14. Bruce SG, Riediger ND, Lix LM. Chronic disease and chronic disease risk factors among First Nations, Inuit and Métis populations of northern Canada - CDIC [Internet]. AEM. 2014 [cited 2020 Apr 30].34(4). Available from: https://www.canada.ca/en/public-health/services/reportspublications/health-promotion-chronic-disease-prevention-canada-research-policy-practice/vol-34-no-4-2014/chronic-disease-chronicdisease-risk-factors-among-first-nations-inuit-metis-populations-northern-canada.html

15. Adegbija O, Hoy W, Wang Z. Prediction of cardiovascular disease risk using waist circumference among Aboriginals in a remote Australian community. BMC Public Health. 2015;15(1):57. doi: 10.1186/s12889-015-1406-1

16. Brown A, Carrington MJ, McGrady M, Lee G, Zeitz C, Krum H, et al. Cardiometabolic risk and disease in Indigenous Australians: the heart of the heart study. Int J Cardiol. 2014;171(3):377-83. doi: 10.1016/j.ijcard.2013.12.026.

17. Armstrong AC, Ladeia AMT, Marques J, Armstrong DMFO, Silva AML, Morais Jr JC, et al. Urbanization is associated with increased trends in cardiovascular mortality among indigenous populations: the PAI Study. Arq Bras Cardiol. 2018;110(3):240-5. doi: 10.5935/abc.20180026

18. Carlos Jr. EAC. Health and indigenous peoples in Brazil: reflections based on the First National Survey of Indigenous People's Health and Nutrition. Cad Saúde Pública. 2014;30(4):855-9. doi: 10.1590/0102-311X00031214

19. Souza Filho ZA, Ferreira AA, Santos J, Meira KC, Pierin AMG. Cardiovascular risk factors with an emphasis on hypertension in the Mura Indians from Amazonia. BMC Public Health [Internet]. 2018 [cited 2020 Apr 30];18. Available from: https://www.ncbi.nlm.nih.gov/pmc/ articles/PMC6234583/

20. Soares LP, Fabbro ALD, Silva AS, Sartorelli DS, Franco LF, Kuhn PC, et al. Cardiovascular Risk in Xavante Indigenous Population. Arq Bras Cardiol. 2018;110(6):542-50. doi: 10.5935/abc.20180090

21. Oliveira GF, Oliveira TRR, Ikejiri AT, Andraus MP, Galvão TF, Silva MT, et al. Prevalence of hypertension and associated factors in an indigenous community of Central Brazil: a population-based study. PLoS ONE [Internet]. 2014 [cited 2020 Apr 30];9(1). Available from: https://www.ncbi. nlm.nih.gov/pmc/articles/PMC3904906/ 